Susanne Gretzinger ${ }^{*}$

\title{
Strategic Outsourcing in the German Engine Building Industry. An Empirical Study Based on the Resource Dependence Approach ${ }^{* *}$
}

Outsourcing is an organizational measure that changes the resource dependencies of a company. In this paper, a framework is developed from the perspective of the resource dependence approach to explain strategic outsourcing in the German engine building industry. On the basis of the NIFA panel, which describes the development of this industry in the 1990s, the framework is examined in cross-sectional and longitudinal studies. It can be shown that the resource dependence perspective contributes to an explanation of organizational changes, both outsourcing and insourcing. In addition, the longitudinal studies show the significance of the strategic, that is, long-term orientation of the ensemble of organizational measures towards company success.

Key words: Outsourcing, engine building industry, resource dependence approach, panel study

* Dr. Susanne Gretzinger, Ass. Professor, Department of Border Region Studies, University of Southern Denmark. E-mail: sug@sam.sdu.dk.

** I would like to thank Martin Spieß (DIW/Soep Berlin/Universität Hamburg) for the discussion on the imputation of missing values, and my reviewers for their important suggestions.

This article is part of special issue Resources and Dependencies, mrev 19(1+2).

Article received: October 25, 2007

Revised version accepted after double blind review: March 15, 2008. 


\section{Introduction}

Outsourcing, on the one hand, is considered as a central element of organization on the way towards modern, that is, "streamlined" organization (Drucker 1988). In Germany, this instrument was quickly adopted, beginning with the familiar cases of the outsourcing of computer services at General Motors and Eastman Kodak at the end of the 1980s (Szyperki 1993). At first, outsourcing was only applied to the realm of information technology, closely adhering to the practical models. But in both practical use and the theoretical discussion of the phenomenon outsourcing, this measure was soon applied to other corporate functions as well (Trossmann 2002). Since then, outsourcing has been considered a central component in the "paradigm of the new decentralization" (Drumm 1996). In normative terms, outsourcing was particularly suggested in industries like the German engine building industry, which exhibit a high degree of vertical integration (Widmaier 2000b).

On the other hand, the problem of organizing business processes effectively and mobilizing them strategically through layers of value creation is an essential question of business economics theory. Accordingly, outsourcing was equated with the more fundamental "make or buy" decision (Walker/Weber 1984). The discussion of whether services are most advantageously provided within a business or by others through the market is often held with a one-sided emphasis on outsourcing. This onesidedness corresponds with the recent orientation of business organizational theory solely according to economic theory. Both the new economics of institutions, in particular the transaction costs approach, as well as the "resource based view of the firm" are now being discussed in Germany in connection to outsourcing in practical application with a recommendation towards the market (Matiaske/Mellewigt 2002). On a theoretical level, a framework needs to be established that considers insourcing as well as outsourcing as organizational options. Empirically speaking, it is advantageous to consider outsourcing or insourcing in the course of time as an organizational option.

This study explores the determinants, motifs, and success of insourcing and outsourcing in the German engine building industry. In contrast to the mainstream of German research, the focus here will not be placed on taking stock of these measures, but on examining the frame of reference for explaining the phenomenon, following the resource dependence perspective and linking Pfeffer/Salancik's (1978) classical argument with the concept of strategy. Empirically, the study is based on panel data regarding organization in the German engine building industry, the so-called NIFA panel (Widmaier 2000a).

In section two, I will sketch out the framework for explaining outsourcing. The third section presents the German engine building industry and explains the situation of the industry on the base of the NIFA panel. Section four presents central hypotheses that will be tested in the empirical part. In the fifth part, I will present the data basis and descriptive statistics, as well as cross sectional and longitudinal models on the determinants and consequences of outsourcing. The results are then summed up in the conclusion, where remaining questions are discussed and further areas of needed research are proposed. 


\section{Outsourcing: A Resource Dependence Perspective}

The term outsourcing - an artificial word constructed from the words "outside" and "(re)sourcing" - has undergone a significant expansion in the course of the discussion. Initially only applied to the outsourcing computing services, the term soon became neutral in terms of function, that is, it was used to described the random outsourcing of economic functions of companies. Furthermore, it was pointed out early in the theoretical discussion that the decision about outsourcing also includes the possibility of insourcing (Walker/Weber 1984; Picot 1991). To distinguish the use of outcompany services from the use of services within the parent company, a distinction is also made between "external" and "internal" outsourcing. This theoretically significant distinction is difficult to operationalize in empirical studies like this one (Matiaske/Kabst 2002). In the following, outsourcing refers to the external as well as internal outsourcing of various economic activities to an external organization with its own independent legal status. Accordingly, insourcing means the "insourcing" of activities once done outside the company. Resourcing is used as a general term.

According to the thematic character of organizational measures, to explain outsourcing approaches are used that focus on resources and on organizational exchange relationships: the transaction cost approach, the "resource based view of the firm" and the "resource dependence approach". Before presenting the basic tenets of the approach favored here, I will sketch out the competing explanations and their difficulties when it comes to the phenomenon of resourcing.

While in German outsourcing research, the transaction cost approach (TCA) (Williamson 1985, 1986) has primarily found its way into the theoretical discussion, but not as a reference in empirical studies. This is not true to the same extent in the English speaking world, where the literature includes many studies on outsourcing ${ }^{1}$ that take recourse to the TCA of the Williamsian variety (for example Aubert et al. 1996; Ang/Cummings 1997; Poppo/Zenger 1998; Klaas et al. 1999). In terms of outsourcing, the argument behind this approach focuses on two determinants that influence the extent of transaction costs: factor specific investment on the one hand and uncertainty regarding the transaction partner on the other. ${ }^{2}$ If no or only minimal factor specific investments are necessary and the possibility of opportunistic behavior on the part of the transaction partner can be neglected, than both the empirical hypothesis and the normative suggestion considers outsourcing as advantageous.

In the context of the discussion on outsourcing, this argument has met with criticism. The criticism is made that the TCA is solely interested in the minimization of transaction costs, but is not concerned with the maximization of profits (Mellewigt 2003). This objection fails to recognize that the approach treats a situation of choosing among several different advantageous options for the organization. More relevant are the points raised by Langlois (1988) and Zajac/Olson (1993). Langlois brings at-

1 A current overview of empirical studies and their theoretical background is provided in Gretzinger (2008).

2 The third determinant emphasized by Williamson (1986), the frequency of the transaction plays a subordinate role in the empirical studies. 
tention to the fact that the comparatively static orientation of the approach neglects the dynamics of the central variable of transaction costs in relationships of exchange. Put in more abstract terms, TCA overlooks the strategic character of outsourcing relationships, or, in other words, the argumentation proves to be not foresighted enough. Similarly, Zajac/Olson argue with an eye for the strategic character of network relationships that are neglected in TCA, in their view.

In contrast, the strategic element neglected in TCA when it comes to shaping relationships of exchange outside the organization, one that takes on a decisive importance if uncertainty is assumed as a starting point, is central to the "resource based view of the firm" (RBV). In the central work on the approach, Penrose (1959) already emphasized the entrepreneurship character of decisions in business economics, taking recourse to classical positions. But in the contemporary reception and further development of this line of argumentation (Wernerfeldt 1984, 1995, Turvani 2001), RBV stands for an emphasis on internal resources of organization. The concentration on core competencies (Prahalad/Hamel 1990) has become a keyword for characterizing the argument in the approach to outsourcing. Briefly, the approach predicts and suggests a strategic orientation of the organization that protects the ensemble of resources specific to the organization from imitation and creates lasting competitive advantages.

This approach has undoubtedly grown to become one of the most frequently used references in corporate research and above all in strategic management. All the same, there are several points of criticism that have yet to be dismissed in the debate. On the one hand, even proponents of the approach like Mellewigt (2001) point out that the central concepts remain unfocused, and this involves difficulties when it comes to operationalization. On the other hand, due to its emphasis on corporate resources the resource based view neglects market forces (Freiling 2001). To put it more pointedly, the approach overlooks the relational character of economic processes. Foss/Foss (2004) accordingly demand an integration of transaction cost arguments. Other authors want to develop the approach into a "relational view", in order to integrate the resources available in networks (Duschek 2004).

The "resource dependence approach" (RDA), developed by Pfeffer/Salancik (1978) as an alternative to the then dominant contingency approach, does not exhibit these limitations of the competing theories. Processes of exchange are central to RDA, and so-called critical resources and a power structure linked to this can be derived. To the extent that resourcing entails a rearrangement of resource dependencies, the approach is accordingly good for the purposes of explanation (Nienhüser 2008). In contrast to RBV, the power-theoretical foundation of the approach endogenizes the relational character of the economic process of exchange. That it is also able to grasp organizational measures under strategic aspects will be explored in the following. We can already state that there are good reasons to prefer RDA in developing an explanatory framework. But all the same, RDA, at least in the German-speaking world, might be frequently cited in the literature, but it is rarely used in empirical studies (Hermesch 2002, Nienhüser 2008).

A starting point for the development of the Resource Dependence Perspective (RDA) was a dissatisfaction with the contingency approach in organization research 
and its inherent determinism. A second point of criticism was the hodgepodge of various variables of influence on the organizational structure in the contingency approach that resulted from the empirical interests of the researchers and was not structured by a theoretical argument. In response to both objections, Pfeffer/Salancik (1978) suggested taking recourse to a sociological conception of the theory of exchange and or power (Emerson 1962). With the contingency approach, they share a focus on external determinants of organizational behavior. All the same, they open with their perspective the closer examination organizational internal decision processes to the extent that the theory of power is also applicable. For the following considerations, however, this aspect is only of secondary interest.

Central to RDA is the economic agent, as a rule a corporate actor (agent) or an organization that is seeking to improve its situation. That is, the behavior of organizations is conceived in the approach as outfitted with egoism on the one hand and bounded rationality on the other. The goal of organizations is to survive on the market over the long term. According to this key statement of the approach, organizations try to improve their situation by decreasing their resource dependency.

In the definition of resource dependency, Pfeffer/Salancik (1978) take recourse to Emerson's so-called relational Theory of Power (1962). Emerson understands interactions between individual or corporate actors as essentially exchange relations. In these exchange relations, the actors are dependent on the resources of other actors. The dependency of one Actor A on Actor B is defined here by the interest of A in resources under the control of exchange partner B. That is, the extent of power of B over A is first of all a function - in economic terminology - of the demand of A. In this way, a perspective has been found that brings order to the collection of situational factors influencing organizational structure. Only those factors that organization A is dependent upon or for which a demand develops secure influence on the focal organization for an actor B. In the abstract perspective of his power theory, Emerson already opened the possibility of strategic action: $\mathrm{A}$ is all the more dependent the less there is a possibility of receiving the resource of interest outside the A-B relationship.

Pfeffer/Salancik (1978) develop their approach on the basis of this theory of power, which in economic terminology sees power as a function of supply and demand. ${ }^{3}$ Among other things, they suggest a series of classifications and explain possibilities of organizations to influence the relationships of dependency. Foundational for their argumentation is the consideration that organizations are dependent on critical resources, that are, those resources necessary for the survival of the organization or, formulated differently, resource dependencies in terms of which they are particularly vulnerable, avoid or should avoid.

At first glance, this argument is similar to that of RBV. But "critical resources" are not necessarily congruent to "core competencies." For example, electricity produc-

3 The link to economic core theory has been clarified in recent discussions of models of exchange theory. The point of reference here is above all the Coleman model (Coleman 1990), that grasps the social exchange in analogy to microeconomic theory. From this point of view, Emerson's power theory can be reconstructed more precisely as a dyadic monopole situation. On this see Matiaske (2009). 
tion is surely not a core competency of hospitals. All the same, contemporary medical treatment, especially in operating rooms, necessarily relies on electricity in order to operate medical devices. This means that modern hospitals are particularly vulnerable in the realm of electricity supply, and endangered in their survival. So although electricity generation does not represent a core competence of hospitals, they must secure this critical resource, and from a RDA point of view it would be advantageous to have access to emergency generators.

Dependence on critical resources in particular is a variable influencing organizational behavior. A second results directly from the assumption of bounded rationality. With imperfect information about possible states of the environment, resources are now more or less securely available. That is, Pfeffer and Salancik (1978) interpret uncertainty as an independent variable of organizational behavior. Decisive for the character of uncertainty are the distribution of actors and resources in the consideration of net value and the relationships between actors (Aldrich/Pfeffer 1976). For an organization, uncertainty in terms of resources is all the greater the more scarce the resources needed are (critical resources), the less actors offer them, and the more connections there are between providers. Subjective expectations and perceptions thereby influence the codification of scarcity and the interpretation of the positions of the interaction partners in the network structure. In other words, the assumption of bounded rationality implies as well that a subjectively interpreted uncertainty should be assumed (Hermesch 2002, Pfeffer/Salancik 1978, 88).

Strategic considerations influence the choice and the character of the variants of action. In the sense of RDA, the term corporate strategy can be defined as a long-term targeted influence of the resource dependence situation of the company to secure its own continued existence. For the continuous implementation of a corporate strategy, the actors develop intersecting ensembles of measures, including marketing and product strategy. They can be interpreted as typified programs of action or patterns. Organizations as bounded rationally active agents establish these programs, to not have to react to each change in the environment in cause of resource dependences and uncertainty. Comparable to individually limited rationally acting figures that act with activity routines or scripts in typified definitions of the situation, organizations use strategies to orient themselves over the long term to relevant parameters. ${ }^{4}$

Pfeffer/Salancik (1978) discuss beyond these foundational mechanisms a series of possible ways that organizations can control their dependence and the uncertainty of influences on resource availability. The basic assumption is that organizations do not behave passively or adaptively to their surroundings. Instead, management undertakes measures to shape organizational dependence. For example, by way of storage or the

4 The concept of "definition of the situation" can be found in the organization research of March/Simon (1994). For an extensive treatment of this issue, see Matiaske (2009). Here, furthermore, a preparation of this notion in the form of a layered concept of rationality. According to his, intentionally rational actors act in known and typical situations on the basis of tried routines. These were cause when changes surfaced as disturbances of longterm definitions of the situation that resulted in a revelation. 
substitution of supply sources, dependency and uncertainty are reduced. Resourcing is thus a means for changing organizational dependency. ${ }^{5}$

These considerations are summed up in figure 1. The resource situation of the organization, described in terms of dependence and uncertainty, has on the one hand an influence on the choice of business strategies and influences directly and by way of the strategic option of organizational measures of insourcing or outsourcing. With minimal dependency and uncertainty, organizations can make a decision solely on the basis of the price for make or buy. Otherwise, they will attempt to avoid dependences and opt against outsourcing or for the resourcing of a service once provided by an outside provider.

Figure 1: Model: Strategic sourcing

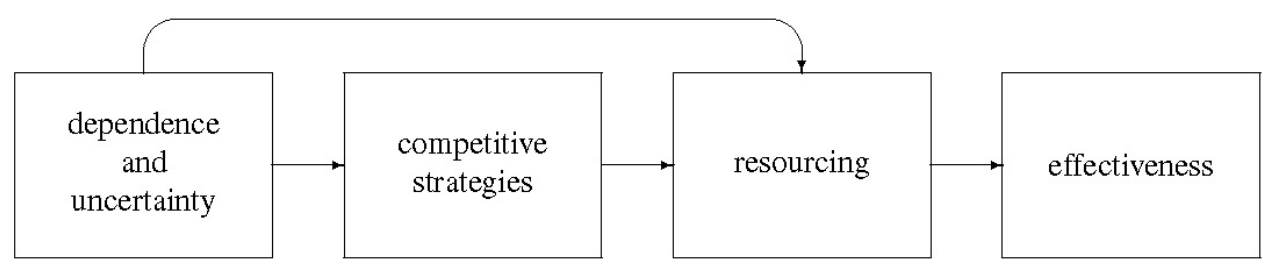

\section{The German engine building industry in the 1990 s}

The engine building industry is considered the backbone of industrial production. In Germany, analogous to the late industrialization, this industry first began to develop in the 1850s. At this time, the first textile machine and tool machine factories emerged as well as special applications closely linked to developments in the mining, shipping, and armaments industries (Hirsch-Kreinsen/Seitz 2000). Until the late 1920s, the German engine building sector was largely decentrally organized, and large parts of it remain so today. The market required no mass production, and could served by small and midsized companies. With the exception of wartime preparations in the 1930s, a certain kind of mass production developed due to the demand for complex mechanically automated systems only in World War II (Delmestri 2002). Although in Berlin and Saxony large producers were now destroyed by the war, the German engine building industry could be rebuilt quite quickly. The West German engine building industry reached its highest level of employment in 1971, when with 125,000 employees it became the worldwide largest producer and exporter (Maurice/Sorge 1990; Delmestri 2002). In the 1980s and 1990s, the sector came under competitive pressure as part of globalization.

Far Eastern engine builders, especially Japanese ones, now competed with West German companies on the world markets. In the course of this development, atten-

5 Pfeffer/Salancik (1978) distinguish among four measure ensembles: Management of the environmental relations, changes to the situation of dependence, negotiations with surrounding actors, and lobbying. Internal and external outsourcing can be more precisely placed in the bundle of measures changes and or negotiations. For more on this, see Gretzinger (2008). 
tion was increasingly turned toward technological and organization in engine building, as well as organizational changes in manufacturing. On the one hand, it was pointed out that the series of Japanese companies were four to eight times greater in number that the small series typical of German companies of 100 tool machines per type and month (Vieweg/Hilpert 1993). Before this backdrop, a reduction of the real net output ratio was expected and/or the application of outsourcing was promoted (Beutin et al. 2003). The scholarly interest in the expected changes was one reason for the establishment of the NIFA panel. In retrospect, it can be established that the companies chose various measures of adapting. While one part reduced the component of mechanical manufacturing, decreased staff and increasingly used outsourcing activities, not all companies followed this trend of streamlining in view of core competencies. Mid-sized and large companies in particular have increasingly integrated more and more functions into production (Leyendecker 2000) and use the integration into networks with customers in a sense as their core compentence. This variation in reaction to the crisis makes this industry interesting for the organizational research on the empirical base of the NIFA panel.

Table 1 describes the structure of the industries in the time period of observation on the basis of the NIFA Panel. Based on an average of around 1700 companies for the time period 1992 to 1998, the average workforce of the companies in this industry of largely small and mid-sized companies sank from 186 employees to 128 employees. At the same time, the turnover in the same period fell from an average of 42 million $\mathrm{DM}$ to around 33 million DM. This change corresponds on the one hand with the streamlining of the companies as well as the general business climate. All the same, the subjective success outlook was not always negative. After the poor assessment at the start of the 1990s, beginning in 1994 again positive success outlooks can be seen. One should take into consideration that around 32 percent of the businesses are under the roof of a parent company.

Table 1: Business organization, turnover and prospects of success

(Quelle: NIFA-Panel 1992-98, own calculations)

\begin{tabular}{l|c|c|c|c|c}
\hline Jahr & $\mathrm{N}$ & $\begin{array}{c}\text { (Number of } \\
\text { personnel) }\end{array}$ & $\begin{array}{c}\text { Turnover } \\
\text { (in Mio. DM) }\end{array}$ & $\begin{array}{c}\text { Prospects of } \\
\text { success }^{* *}\end{array}$ & $\begin{array}{c}\text { Linked with } \\
\text { parent companies }\end{array}$ \\
\hline $1992^{*}$ & 1698 & 186,30 & 42,28 & $-0,14$ & 32,49 \\
\hline $1993^{*}$ & 1500 & 183,53 & 41,74 & $-0,20$ & 33,37 \\
\hline 1994 & 1854 & 167,51 & 34,97 & 0,50 & 32.91 \\
\hline 1995 & 1652 & 151,19 & 31,72 & 0,38 & 32,91 \\
\hline 1996 & 1695 & 140.67 & 33.97 & 0,25 & 33,19 \\
\hline 1997 & 1697 & 143,42 & 33,95 & 0,53 & 31,74 \\
\hline 1998 & 1615 & 128,02 & 33,21 & 0,48 & 35,98 \\
\hline Total & 11711 & 157,16 & 35,77 & 0,27 & 32.06 \\
\hline
\end{tabular}

* except East-Germany

${ }^{* *}$ additive scale (demand, turnover und outcomes);

Spread - 2 bis +2 (with extreme characteristic „significant increase") 
At the same time, over the course of time the manufacturing programs of the engine builders have also changed. Table 2 reports calculations on the basis of the NIFA panel. At the same time, it becomes clear that the portion of single product manufacturing, that is, manufacturing solely for customer specifications, briefly decreased in 1995, but increased immediately afterward and until the end of the period of observation was 1.5 percent points above the starting level of 1992. But the portion of products made to meet customer specifications rose from 52 percent in 1992 to around 60 percent in 1998. With these changes, there is an expansion of the quotient of skilled workers in production - and parallel to this a drop in the unqualified workforce of around 4 percent.

Table 2: Structure of personell and type of production

(Reference: NIFA-Panel 1992-98, own calculations)

\begin{tabular}{l|c|c|c|c|c}
\hline Jahr & N & $\begin{array}{c}\text { Skilled } \\
\text { labour }\end{array}$ & $\begin{array}{c}\text { Unique } \\
\text { production }\end{array}$ & $\begin{array}{c}\text { High volume production } \\
\text { (Mittelwert in \%) }\end{array}$ & $\begin{array}{c}\text { Customer's } \\
\text { specification }\end{array}$ \\
\hline $1992^{*}$ & 1698 & 46,13 & 34,58 & 16,22 & 52,23 \\
\hline $1993^{*}$ & 1500 & 46,27 & 35,06 & 15,73 & 53,40 \\
\hline 1994 & 1854 & 46,94 & 35,37 & 16,27 & 55,14 \\
\hline 1995 & 1652 & 47,20 & 33,74 & 15,98 & 55,97 \\
\hline 1996 & 1695 & 48,82 & 34,74 & 15,12 & 57,82 \\
\hline 1997 & 1697 & 49,24 & 36,51 & 15,07 & 59,65 \\
\hline 1998 & 1615 & 49,62 & 36,00 & 16,24 & 59,93 \\
\hline Total & 11711 & 47,75 & 35,15 & 15,81 & 56,32 \\
\hline
\end{tabular}

* except East-Germany

\section{Strategic outsourcing in the German engine building industry}

How can these changes be explained? On a RDA basis, external and internal resources should be examined to provide the explanation. Furthermore, as sketched out in the theoretical part, we need to consider corporate strategies in the explanation. Refering to the secondary analytic charakter of this study on the basis of the NIFA panel, only availalbe operationalizations for the resource dependences as well as for the corporate strategy can be considered.

The basic assumptions about the determinants of the outsourcing decision explored in the theoretical sketch allow us to presume that the dependence and uncertainty of the organization on the one hand have a direct influence on organization, while at the same time an indirect influence by way of corporate strategy. In the following, I will first explore the groups of determinants. In the second step of the argument, I will discuss the supposed influences of these determinants on corporate strategies. Finally, in the third section, I will explore influences on the outsourcing decision. Figure 1 provides an overview of possible variables of influence.

As a metatheory of organizational behavior, RDA formulates no specific organizational strategies. Borrowing from fundamental considerations about the classification of competitive strategies (Ansoff 1965 and Porter 1998) and possible operation- 
alizations on the basis of the NIFA panel, I will discuss the distinctions between two possible competitive strategies: innovation and diversification.

In the NIFA panel, the strategy of innovation is operationalized by way of a dummy of a ranked question on corporate strategy (distribution, market expansion, product new planning/innovation, and diversification). That is, companies that place the aspect of new product planning first on a list of possible competitive strategies rely on the operationalizaton of innovation. This strategy is future-oriented and highrisk. It thus has a stable resource basis both in a financial sense as well as in light of the human capital as a requirement. Furthermore, innovations in engine building are often developed together with suppliers or customers. The opposite is true in case of the diversification strategy, which operates as the first choice in the above named choice question. It should reduce extant risks in the future. Accordingly, for the realm of engine building industry it is assumed that the diversification strategy tends to be selected in economically difficult situations, either in general or in reference to the individual business in question.

RDA emphasizes the significance of external resource dependence for the choice of strategic options of organizational structure. In the context of the NIFA panel, two groups of external determinants can be distinguished from one another. The category of framing conditions means on the one hand the assessment of the overall economic situation by those decision makers questioned. On the other hand this includes the existence of an area-wide collective labor contract, in German called a Flächentarifvertrag.

This means that in the process of "collective bargaining" a contract has been agreed upon between employers and unions that is binding for all companies operating in an industry in a defined area, a regional division that can surpass federal states. Furthermore the external resource dependences encompass the influence of suppliers and customers - also the sales possibilities are external determinants from the viewpoint of the RDA. The influence on the input and output side of things is operationalized by way of an additive scale ${ }^{6}$ from the point of view of those questioned. Finally, in the category of external resource dependence, can be objectively operationalized to procentual turnover quotient with core customers, the existence of cooperation in an association (dummy) as well as long-term customer relations (dummy).

The option for or against outsourcing is furthermore determined by way of internal resource dependencies. Analogously to the external dependences explained above, in reference to internal framing conditions we can distinguish between framing conditions, the manufacturing program relevant for supplier and customer influence, and existing human resources. The internal framing conditions comprise the variables of concern association, the relationship to the work council, and the current orders. The dummy variable association with concern is of relevance for outsourcing because it includes the aspect of internal and thus from focal companies controlled outsourcing over a pure market relationship. The work council plays a decisive and increasingly strong role in the German system of labor relations (Müller-Jentsch/Seitz 1998). Decisions in the realm of personal management not directly of an economic nature re-

6 See indications on operationalization in the appendix. 
quire the consent of the work council, that is, without their cooperation, management cannot make any legally binding decision. All the same, as we know from a wellfounded conclusion of German industrial relations research, not de jure relationships, but de facto relations between management and work council are of interest (Kotthoff 1994). NIFA not only asks about the existence of a work council, but also the quality of the relations with that council. Here, cooperative relations to the work council are introduced as a dummy variable. The state of orders measured in weeks signals the resource independence of the focal environment vis-à-vis the sales market.

The structure of the manufacturing program in engine building is operationalized using three variables. The portion of custom made production and/or manufacturing according to customer specifications captures the degree of dependence on the sales market. The portion of manufacturing without commission signals the degree of independence from customers. Finally, the variables on human capital available control the size of the organization, their portion of expert employees the independence of the focal corporation or the general possibilities or necessities of using certain measures of outsourcing.

Table 3 contains the hypothetical relations of influence for the empirical study.

Table 3: Suspected interdependencies

\begin{tabular}{|c|c|c|c|c|}
\hline & \multicolumn{4}{|c|}{ Target variables } \\
\hline & $\begin{array}{l}\text { Competitive } \\
\text { Strategy: } \\
\text { Innovation }\end{array}$ & $\begin{array}{l}\text { Competitive } \\
\text { Strategy: } \\
\text { Diversification }\end{array}$ & $\begin{array}{l}\text { Sourcing- } \\
\text { decision: } \\
\text { Outsourcing }\end{array}$ & $\begin{array}{l}\text { Sourcing- } \\
\text { decision: in- } \\
\text { house-production }\end{array}$ \\
\hline $\begin{array}{l}\text { Intermediate variables } \\
\text { Innovation } \\
\text { Diversification }\end{array}$ & & & $\begin{array}{l}+ \\
--\end{array}$ & $\begin{array}{l}-- \\
+\end{array}$ \\
\hline $\begin{array}{l}\text { External Resource Dependencies } \\
\text { Framework } \\
\text { General economic situation } \\
\text { Labor agreement (zonal fare) }\end{array}$ & + & -- & $\begin{array}{l}- \\
+\end{array}$ & $\begin{array}{l}+ \\
--\end{array}$ \\
\hline $\begin{array}{l}\text { External actors } \\
\text { Influence of the victualers } \\
\text { Cooperation in akquisition } \\
\text { Longterm victualers relationships } \\
\text { Customer's influence } \\
\text { Regular customers turnover } \\
\text { Cooperation in distribution } \\
\text { Longterm customer relationships }\end{array}$ & $\begin{array}{l}+ \\
+ \\
+ \\
+ \\
+\end{array}$ & + & $\begin{array}{l}- \\
+ \\
- \\
- \\
- \\
- \\
+ \\
--\end{array}$ & $\begin{array}{l}+ \\
- \\
+ \\
+ \\
+ \\
- \\
+\end{array}$ \\
\hline $\begin{array}{l}\text { Internal Resource Dependencies } \\
\text { Framework } \\
\text { Linkages with parent companies } \\
\text { Work council (cooperative) } \\
\text { Volume of order in weeks }\end{array}$ & $\begin{array}{l}+ \\
+\end{array}$ & -- & $\begin{array}{l}+ \\
- \\
+\end{array}$ & $\begin{array}{l}-- \\
+ \\
--\end{array}$ \\
\hline $\begin{array}{l}\text { Manufacturing program } \\
\text { Make to order production in \% } \\
\text { Customer's specification } \\
\text { Production without order }\end{array}$ & & & $\begin{array}{l}- \\
-- \\
+\end{array}$ & $\begin{array}{l}+ \\
+ \\
--\end{array}$ \\
\hline $\begin{array}{l}\text { Humanresources } \\
\text { Employees } \\
\text { Skilled worker in \% }\end{array}$ & + & + & -- & + \\
\hline
\end{tabular}


According to the central RDA assumption, a high-risk innovation strategy is only chosen if the company finds itself in a positive economic situation, has stable external and internal relations, and furthermore possesses with a human capital basis that is favorable to innovation, with a quotient of expert labor. The diversification strategy, in contrast, is a possibility of resisting the external influence of providers or customers in poor general or individual economic situations, in order to gain options and for large organizations to minimize the risk of a specific manufacturing program. The innovation strategy tends to promote outsourcing, for it presumes internally available resources. With this it sinks the in-house production quotient, here considered as the alternative operationalization of outsourcing. Conversely, the diversification strategy should apply to internal resources, that is, the influence on the outsourcing decision is negative, while positive on the in-house production quotient.

Beside the influence on the organization of real net output ratio by way of competitive strategies, direct influences are expected on the external and internal resource dependence situation. Positive overall economic demand (at least over the short term) will increase the degree of utilization and thus the quotient of in-house production. Being bound a general labor contract, which in the case of engine building for the companies entails high labor costs at metalworkers wages, will promote the outsourcing of such services that can be provided more affordably in industries with lower wages.

Long-term cooperation in supply or distribution makes it more possible to outsource activities in these controlled relations. In contrast, outsourcing is not an advantageous strategy for escaping the influence of long-term suppliers and customers. In these cases, control over these relationships is placed in the hands of other organizations: this could possibly lessen resource dependence, but surely increases uncertainty vis-à-vis the long-term suppliers and/or customers.

In the case of association within a larger concern, the advantages of (internal) outsourcing can be used without having to accept the risk of a new resource dependence on external suppliers. Work councils have an interest in maintaining the employment levels of the company, that is, they would tend to resist an outsourcing decision. For the management of the company the work council is a resource that makes it more difficult or eases to access the employees. It can be assumed that management does not want to resource in the case of a cooperative relationship, and accordingly accommodates the interests of the work council. In case of a high order load, in contrast, outsourcing suggests itself due to reasons of capacity.

But, for a highly specific manufacturing program, characterized by unique products and/or products made to meet customer specifications, with an according high quotient of qualified employees, outsourcing is less likely because it does not lower resource dependence.

Dependent variables of the study are on the level of organizational measures the outsourcing decision and the in-house production depth. The real net output ratio was established in the NIFA panel in the year of the survey directly as a percentage; the question of the resourcing decision was introduced to the panel beginning in the fourth wave. The question is posed whether in the year in question production orders 
are outsourced or re-insourced. Since both outsourcing and insourcing are captured in the real net output ratio, in terms of the organizational decision - for reasons of space - I will only include outsourcing in the models. ${ }^{7}$ With the theoretical question of the study in mind, it is useful to consider the reasons or motifs of the decision for operationalizing the outsourcing decision. In the multivariable models, the question of the motifs of outsourcing is combined with the decision for outsourcing. The analyses account for whether outsourcing measures took place, and if this was the case, whether this took place for strategic reasons or for reasons of cost orientation. The variable "strategic outsourcing" is operationalized using the item of outsourcing due to a concentration on core competencies. The core competencies possibly represent only a subset of the critical resources, meaning that this measurement can only be considered approximate. Outsourcing for reasons of cost is also a combination of motifs. The variable is accordingly conceived as a three level indicator (none, for cost reasons, for strategic reasons).

To measure success, RDA uses the effectivity, or more precisely, the "survival capacity" of the organization. The NIFA panel asks questions on key items about company success. These variables, for example turnover, cannot be used without further reference points. Here, an increase in turnover in comparison to the prior year is introduced as an indicator in the longitudinal analysis. In the cross-sectional study, the size of the company (number of employees) is introduced as a control variable.

To measure corporate success, this study also takes recourse to a subjective measure of success. ${ }^{8}$ The NIFA panel regularly asks for an estimation of expected developments in the realms of demand, turnover, and yield. The questions were aggregated under the term "success outlook" to one variable. The internal consistence of this item is $\alpha=0.817$.

\section{Empirical results}

\subsection{The data basis}

The NIFA panel was established to research business, economic, technical and social developments in the use of more flexible systems of labor. The trigger for the panel project was the hypothesis that in the 1990s new forms of organization, production, and business management would come about. The engine building industry was supposed to be particularly effected by these changes. It was assumed that an increased use of computer-supported production technology, decentralized management, as well as taskintegrating forms of work organization would become the norm (Widmaier 2000a).

7 Both variables correspond to one another, for the real net output ratio is the result of prior resourcing decisions. The correlation of outsourcing decisions in 1997 with the prior year's in-house production quotient for outsourcing takes the value $r=0.111$ $(\mathrm{p}=0.001 ; \mathrm{n}=810)$. This means if the company said it undertook outsourcing measures in 1997, this correlates negatively with the in-house production quotient of 1998.

8 This approach is customary in personal and organizational research because objective numbers on the one hand imply significant problems of acceptance, and thus produce lacking answers, as well as at the same time are not informative without further basis for comparison. 
The panel, developed and carried out by a group of researchers at RuhrUniversität Bochum, included a total of eight annual surveys (periods from 1991 to 1998) with a partially shifting focus. Beside a thorough demography of the business (size, legal form, turnover) questions were posed on production, manufacturing technology, group work, factory organization, and relations to the environment. This last complex of issues in particular makes NIFA interesting for analyses from an RDA perspective.

The study was conceived as a written questionnaire. For cost reasons, the advantages of an oral survey were sacrificed in order to be able to realize a complete survey of the German engine-building sector, with 6000 to 8000 companies with more than twenty employees. The questions were directed at the management. To awaken their interest in the questionnaire, partial events and key data were published for benchmarkings. In addition, those questioned were written to several times to raise the return quotient. This remained at a constantly high level of 25 to 30 percent or 1500 to 1854 companies, whereby due to panel mortality the case numbers drop significantly in the long term analyses.

After concluding the project the data was archived at Zentralarchiv für empirische Sozialforschung in Cologne (GESIS ZA) and is available to all interested researchers for secondary analysis.

\subsection{Cross-sectional analysis}

The theoretical model (figure 1) argues for a several-step structure of influence. To translate to an empirical model, a so-called graphical chain model is used (Lauritzen/ Wermuth 1989, Cox/Wermuth 1993). The starting point of a graphical chain model is the illustration of the hypothetical relationships between variables. It is postulated that independent as well as communicating and dependent variables can be distinguished from one another and that there are plausible explanations on the key context of impact. In so doing, variables are grouped in blocks according to their place in the theoretical model. If necessary, connections between the variables are studied on a single level. Furthermore, effects of interactions and non-linear components are accounted for. The assumed relations of influence are translated in the second step to static models. Technically speaking, chain graphs integrate all methods of the general or generalized linear model. This means that in the graphical chain models, both goal as well as influence variables can be of a metric or non-metric nature. Depending on the scale level of the target variables, (logistic) regressions, logit-models or variational analyses are used. ${ }^{9}$

To depict the chain graphs, static partial or block models were formulated. The block model means that based on the first order target variables, on the far right of the illustration, regressions with the variables of all remaining blocks are carried out

9 This is the decisive difference of this variant of soft modeling against harder techniques structural equation modeling such as LISREL, AMOS, or PLS: here, the multi-equation system is not translated into an estimation model, but, depending on the data level of the variables the equations are identified with various models. On the data level of variables the equations are identified with various models. 
with predicators. To the extent that the links between the target variables on the first level are themselves studied, they are also to be specified.

Afterward, block regressions for the target variables are carried out for the later levels. These starting models are now estimated and successively refined by way of the stepwise reverse selection of predicators. Retained in the selection steps are only such variables and or interaction terms that prove significant. What results is a system of regression equations that contains the significant influential variables of the graphical chain.

Figure 2 translates the theoretical considerations and operationalizations on the basis of the NIFA panel into a graphical chain model. ${ }^{10}$ According to the data level of the target variables, in terms of the target variables of the first order Standard OLS (turnover) or ordinal regressions (success prospects) are estimated, in that all left variables could be included. In the step backward, successively all variables are eliminated that possess no significant influence on turnover or success prospects. The single frame for the dependent variables on this level symbolizes that assessment equations take account of the dependences on the same level of dependent variables. Turnover is observed in dependence on the success prospects and vice versa. The double frame around the variable blocks on the third and fourth layers symbolizes that there is no interaction between variables within this block. ${ }^{11}$ In the same way, estimations for the dependent variables of a second and third order are carried out. The estimation of the dependent variable "outsourcing" is the result of a multinomial logit model. The influences on the metric variable in-house production quotient can in contrast be defined with a standard OLS estimation. For the binary variables of strategic options, innovation and diversification, binary logistic models of regression are estimated.

Figure 2: Graphical chain model: Strategic sourcing

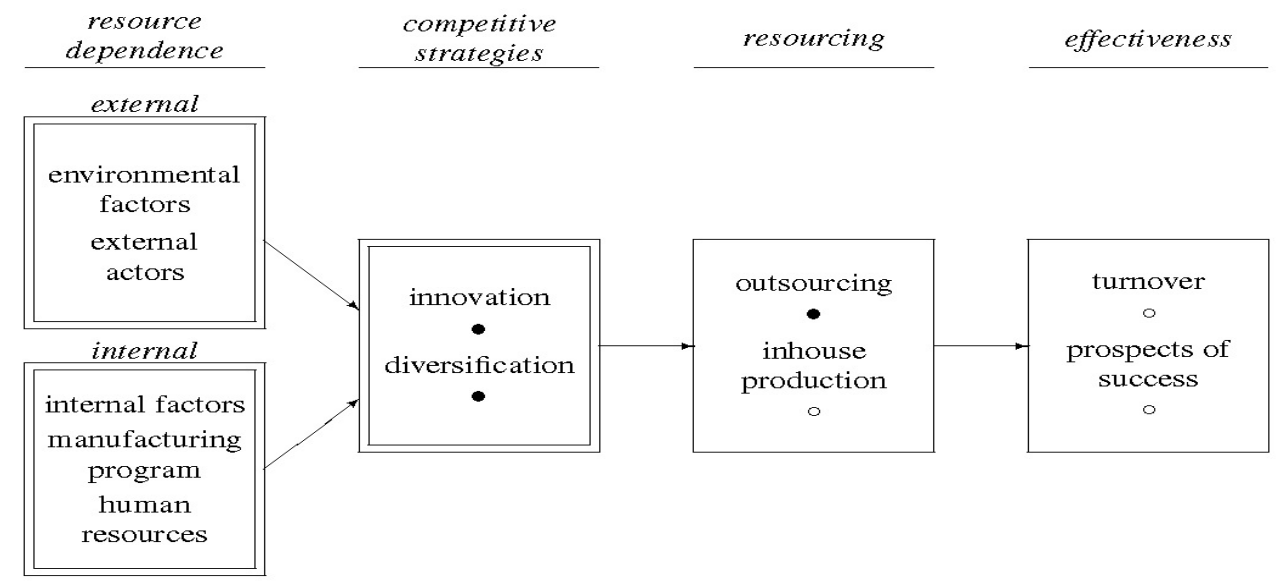

10 In the methodological literature on graphical chain models, it is customary to place the dependent variables on the left, the influential variables on the right. For reasons of consistency, I have deviated from this norm.

11 Furthermore, we looked for non-linear influences of the metrical variables are examined by included quadratic terms. Here there are neither interaction effects nor non-linear terms. 
The results of these analyses are summed up in tables $5 \mathrm{a}$ and $5 \mathrm{~b} .{ }^{12}$ The first partial model looks at turnover, which is here included as an indicator of effectiveness from an RDA perspective as a first-level variable. This does not correspond with the second degree of effectiveness, the success outlook. Of the variables of influence on the second and third level, only in-house production quotient turned out to be a significant predicator. A high in-house production quotient sinks the observed turnover of the engine building companies in light of the other influential variables, especially company size. This relationship can be possibly explained in terms of the concentration on a critical resource in the realm of production technology, that does not coincide with large lot sizes. From the group of external resource dependence factors, cooperation in supply proved a positive predicator, whereby long-term customer relations have a negative influence on the level of turnover. Long-term customer relations are probably a resource that opposes extensive expansion in turnover. Presumably, companies with long-term customer relations invest more resources in maintaining of these relations than for example in measures towards increasing market saturation for higher turnover.

Table 5 a

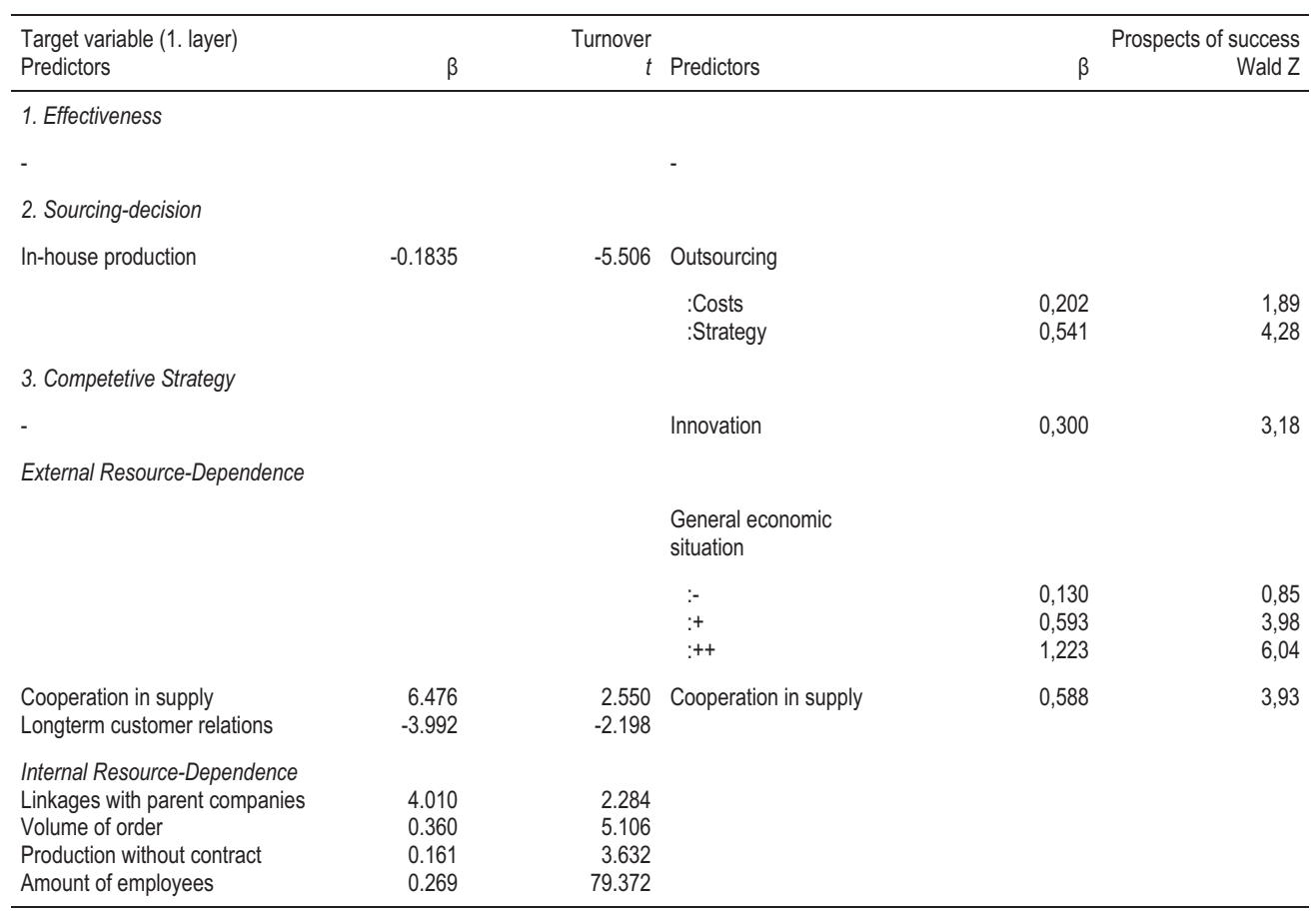

$n=1499 ; \operatorname{adj} . R^{2}=0.839 ; p=0.000$

$n=1510 ;$ Pseudo $R^{2}=0.069 ; p=0.000$

12 The individual estimation equations were examined using variance inflation factors for problems with multi-colinearity. There were no abnormalities to report. The bivariable correlations of all variables are documents in the appendix. 
Table $5 \mathrm{~b}$

\begin{tabular}{|c|c|c|c|c|c|}
\hline \multirow{3}{*}{$\begin{array}{l}\text { Target variable (2. layer) } \\
\text { Predictors }\end{array}$} & \multicolumn{2}{|c|}{ Outsourcing } & & \multicolumn{2}{|r|}{ In-house production } \\
\hline & Costs & Strategy & & & \\
\hline & $t$ & $\mathrm{t}$ & Predictors & $\beta$ & $t$ \\
\hline \multicolumn{6}{|l|}{ 2. Sourcing decision } \\
\hline \multirow[t]{3}{*}{ In-house production } & -3.047 & -3.563 & Outsourcing & & \\
\hline & & & :Costs & -2.557 & -1.379 \\
\hline & & & :Strategy & -6.576 & -2.871 \\
\hline \multicolumn{6}{|l|}{ 3. Competitive Strategy } \\
\hline \multicolumn{6}{|l|}{-} \\
\hline \multicolumn{6}{|l|}{$\begin{array}{l}\text { External Ressource- } \\
\text { Dependence }\end{array}$} \\
\hline Influence of suppliers & 1.559 & 3.372 & Longterm supplier relations & -7.859 & -4.228 \\
\hline Influence of customers & 0.226 & 2.254 & Turnover regular customers & 0.159 & 4.070 \\
\hline Longterm customer relations & -0.033 & -2.093 & & & \\
\hline \multicolumn{6}{|l|}{$\begin{array}{l}\text { Internal Ressource- } \\
\text { Dependence }\end{array}$} \\
\hline Linkages to parent companies & 1.416 & 2.311 & Linkages to parent companies & -7.856 & -4.320 \\
\hline \multicolumn{6}{|l|}{ Work council } \\
\hline :against & 0.815 & 2.433 & & & \\
\hline :difficult & 2.829 & 3.912 & & & \\
\hline :non participating & 0.782 & 0.712 & & & \\
\hline :cooperative & 3.055 & 3.597 & & & \\
\hline Volume of order & 2.752 & 3.723 & Volume of order & -0.322 & -4.374 \\
\hline Made to order & 3.786 & 1.269 & Customer's specification & 0.082 & 3.495 \\
\hline \multirow[t]{3}{*}{ Manufacturing without order } & 1.921 & 2.607 & & & \\
\hline & & & Employees & 0.005 & 2.127 \\
\hline & & & Skilled worker & 19.648 & 4.621 \\
\hline$n=1590 ; p=0.000$ & & & $n=776 ;$ adj. $R^{2}=0.168 ; p=0.00$ & & \\
\hline Target variable (3. layer) & & Innovation & & & Diversifikation \\
\hline Predictors & $\beta$ & Wald Z & Predictors & $\beta$ & Wald Z \\
\hline \multicolumn{6}{|l|}{$\begin{array}{l}\text { External Resource- } \\
\text { Dependence }\end{array}$} \\
\hline Cooperation in supply & -0.454 & -2.64 & - & & \\
\hline Cooperation in distribution & 0.456 & 3.21 & & & \\
\hline \multicolumn{6}{|l|}{ Internal Resource- } \\
\hline \multicolumn{6}{|l|}{ Dependence } \\
\hline Volume of order in weeks & 0.013 & 2.69 & - & & \\
\hline Made to order production & -0008 & -5.44 & & & \\
\hline
\end{tabular}

The most important predicator is in a trivial sense the number of employees. In the realm of internal resource dependence, the goods in order (order list) should also be pointed out as a significant predicator. Since high order levels culminate directly in turnover, we need not explain any further the reasons. The degree of concern- 
association and "manufacturing without order" impact positively on the variable turnover. The impact of concern association can be valued as evidence of vertical integration. The positive impact of the predicator "manufacturing without order" indicates than lot sizes and mass manufacture play a subordinate role in the engine-building sector, but there are several companies that successfully implement these variants. The variables of work relations to the bivariate correlations, relevant due to bivariate correlations - wage relations and relations to the work council - in contrast prove to be significant influences when considered multi-variationally.

The second partial model on effectiveness looks at success prospects. Conversely to the findings in terms of the influence on turnover, this remains of no importance for success outlook. The primary predicators among variables on the second and third levels of the target variables include outsourcing as well as the choice of innovation strategy. The predicator outsourcing is here only significant in the category "strategic outsourcing." The significance of strategic outsourcing makes itself felt here. The significance of the predicator innovation strategies shows that innovation represents a critical resource for engine building. It plays a key part in the success prospects of engine building companies. Both using the outsourcing reasons in the choice of a competition strategy it becomes clear that for the engine building industry quality represents a significant resource. On the level of external resource dependence, the overall economic situation has a positive impact on the success prospects. A further predicator is the level of cooperation in terms of supply. Here it becomes clear that cooperation in supply improves the dependence situation of the company and its success outlooks.

The third partial model gathers the findings on the target variable of outsourcing. In contrast to the other partial models, at issue here is a multinomial regression model. That is, influences are provided relative to the basic category "no outsourcing" as well as for the categories "outsourcing for cost reasons" or "for strategic reasons." In the interest of simplicity, we have reported only the sign and the t-values. We can first of all report that the outsourcing decision in multivariational consideration, as expected, corresponds negatively with the in-house production quotient. In contrast to the hypothesized relations of influence, at least in terms of the relevant category of strategic outsourcing, both a strong supplier base as well as a strong customer influence proved positive predicators. Engine building companies did not escape dependence on their suppliers through increased in-house production, but made use of the possibility of outsourcing in this relationship as well. In contrast, as expected, long-term customer relations lower the choice of the strategic option of outsourcing.

As expected, among the group of internal resource influences concern association as well as the orders level foster the decision to outsource. One unexpected result, on contrast, was the influence of the work council. Contrary to the assumption that the option of outsourcing is selected to avoid internal conflicts with the work council, this measure is also chosen when the work council behaves cooperatively in the view of company management. However, if the attitude of the work council is seen as an ordinal variable, the relationship is to some extent not linear. This means that outsourcing as assumed in the hypotheses, is on the one hand used as a means to escape the influence of a non-cooperative work council, but is also chosen with the support of the 
work council. Only in the case of a passive or ignored work council does the option of outsourcing remain unconsidered. In line with the hypotheses, the variables affect the shape of the manufacturing program. In the case of a high quotient of made-to-order (unique) production, outsourcing is not considered a strategic option, but only chosen for other reasons. A high production quotient without orders, in contrast, has a positive impact on the decision to outsource.

The fourth partial model considers the in-house production quotient that is here integrated as an indicator for the outsourcing decision in the understanding of the RDA as a target variable that is integrated on the second level. On the second level, the in-house production quotient directly corresponds with outsourcing for reasons of cost as well as strategic outsourcing. It proves on the one hand that that in the outsourcing measures at issue are at least over the midterm in- or outsourcing. The awarding of contract in reason of an output peak beyond the capacity in contrast should have no influence on in-house production. The comparison between the two outsourcing variants points on the other hand to the fact that strategic outsourcing by far has more influence than outsourcing for reasons of cost. The choice of a competitive strategy proves not to be a significant predicator in relation to in-house production. Among the field of variables of external resource dependence, the long-term supplier relations and the concern association prove to be significant predicators with a negative effect. As hypothesized, long-term supplier relations improve the power basis of the company that favors outsourcing measures. Access to secure outsourcing providers is present in case of concern association. The predicators with core customers and manufacturing according to customer specification prove, as hypothesized, to be positive factors on the quotient of in-house production. A high degree of orders in hand, in contrast, sinks the degree of vertical integration. Here, it can be presumed that at issue is outsourcing for reasons of maximizing the utilization of the company's own production capacities. As expected, the control over the critical resource human capital increases the portion of in-house production. This is especially true if the quotient of qualified expert labor at the factory is very high.

The remaining partial models analyze the determinants of the competition strategies. Here, no predicators can be reported of risk-minimizing diversification strategies. In terms of the strategy option, in contrast, the determinants can be established that agree with the hypothesis. As supposed, innovation was chosen in a stabile environment. The valuation of the economic situation remained without significance; a high order level in contrast increases the chance that the engine building companies will innovate.

In terms of the other indicators of external resource dependence, on the basis of the prior findings that only relations in sales (cooperation in distribution, long term customer relations) and not also effective in the relations in supply cooperation, contrary to expectations, are negative in terms of innovation strategy. Perhaps they have an impact in an understanding of purchases as a substitute to innovation in their own program of manufacturing. But without a theoretically derived hypothesis, a negative influence of the portion of custom production can be established. Perhaps this variable of innovations in direct collaboration with customers that is expressed in the subjective valuation of the competition strategy. A high quotient of qualified labor, in 
contrast, as predicted, an internal resource that is considered in the decision to choose an innovation strategy.

This study presumes that companies can escape dependence on suppliers and customers by way of insourcing. On the basis of the findings, this is not only true of the operationalizations of the "supplier" or "customer" influence. Instead, the engine building companies use the option of strategic outsourcing in situations of strong supplier or customer influence on staff and investment planning, also on work process and organization as on the manufacturing program etc. This strategic choice is possibly a chance to secure critical resources. This means that in a situation of a high influence on the part of the suppliers or customers, companies can by way of strategic outsourcing measures for alternative suppliers and/or markets. This can, however, only be assumed ad hoc. Contrary to the hypothesis are also the findings on the influence of the work council. A cooperative work council as well as a work council considered difficult by company management both have a positive impact on the choice of strategic outsourcing measures. But if strategic outsourcing measures, as shown by the first level of the chain graph modeling, increase a company's success prospects, this finding is plausible. Cooperative work councils will act in the interest of the long-term success of the company and in this perspective also support strategic outsourcing measures that promise future success.

\section{Panel analysis}

Panel analyses exhibit a number of advantages in comparison to cross-sectional evaluations. With their simultaneous analysis of several waves, they use information better and provide a stronger empirical argument in terms of impact due to their accounting for the temporal component. It is only possible to speak of causality instead of correlation if the consequences of organizational measures on the temporally delayed success of companies can be shown. In the econometric literature, one particular methodological advantage of panel studies has been emphasized: in panel analyses unobserved influence variables can be controlled by forming a difference between the survey periods for the assessment of the temporal effect in the estimation models (Stock/Watson 2003, Wooldridge 2006).

The following analyses account for the last four survey periods of the NIFA panel, that is, the years 1995 to 1998 . Included are indicators of effectivity as target variables, the predicators on the second and third level of the chain graph as well as two determinants of the resources dependence configuration chosen on the basis of the presented evaluation of selected determinants. They are all available for the entire time period and prove significant in the cross-sectional valuations: furthermore, the company size (number of employees) and the estimation of the overall economic situation are considered as control variables. ${ }^{13}$

13 Unfortunately, for the sixth survey wave in 1996 we have no data on competitive strategy. This limits our possibilities for analyzing the results of a strategy shift. To include the remaining information of this wave in the analyses, the lacking information is equated to strategy with the values from the previous year. 
The results of the panel studies are provided in tables $6 \mathrm{a}$ and $6 \mathrm{~b}$. Models 1 and 2 use all information available from all four waves of surveying. This means that at issue here, technically speaking, are so-called unbalanced panel designs that also include cases not observed over the entire period of time. Cases with missing values, however, remained unpredictable. In variant (a) the results of a so-called "fixed regression" were reported.

Table 6 a: Longitudinal surveys

\begin{tabular}{|c|c|c|c|c|}
\hline \multirow{2}{*}{$\begin{array}{l}\text { Target variables } \\
\text { Predicators }\end{array}$} & \multicolumn{2}{|c|}{ (1) Turnover } & \multicolumn{2}{|c|}{ (2) Prospects of success } \\
\hline & (a) & (b) & (a) & (b) \\
\hline In-house production & -0.008 & -0.000 & -0.001 & -0.002 \\
\hline $\begin{array}{l}\text { Outsourcing } \\
\text { :Costs } \\
\text { :Strategy }\end{array}$ & $\begin{array}{r}0.656 \\
-0.295\end{array}$ & $\begin{array}{r}0.643 \\
-0.776\end{array}$ & $\begin{array}{l}0.366^{* * *} \\
0.425^{* * *}\end{array}$ & $\begin{array}{l}0.363^{\star * *} \\
0.425^{\star * *}\end{array}$ \\
\hline Innovation & -0.805 & -0.538 & $0.111 \neq$ & $0.133^{*}$ \\
\hline Diversification & 1.794 & $1.626 \ddagger$ & -0.079 & -0.099 \\
\hline $\begin{array}{l}\text { General Economic } \\
:- \\
:+ \\
:++\end{array}$ & $\begin{array}{l}-0.233 \\
1.547 \ddagger \\
1.366\end{array}$ & $\begin{array}{r}-0.848 \\
0.044 \\
1.196\end{array}$ & $\begin{array}{l}0.457^{* * *} \\
0.934^{* * *} \\
1.251^{* * *}\end{array}$ & $\begin{array}{l}0.369^{* * *} \\
0.772^{* * *} \\
1.049^{* * *}\end{array}$ \\
\hline Employees & $1.167^{\star \star *}$ & $1.170^{* * *}$ & -0.000 & -0.000 \\
\hline $\begin{array}{ll}\text { Year } & \text { :1996 } \\
& : 1997 \\
& : 1998\end{array}$ & & $\begin{array}{l}1.449^{*} \\
4.730^{\star * *} \\
4.612^{\star * *}\end{array}$ & & $\begin{array}{l}-0.393^{* * *} \\
0.144^{* *} \\
-0.058\end{array}$ \\
\hline$n$ & 2674 & 2674 & 2674 & 2674 \\
\hline obs & 5064 & 5064 & 5064 & 5064 \\
\hline $\mathrm{R}^{2}$ & $0.163^{* * *}$ & $0.175^{\star * *}$ & $0.048^{\star * *}$ & $0.066^{\star \star \star}$ \\
\hline Target variables & \multicolumn{2}{|c|}{ (3) Turnover } & \multicolumn{2}{|c|}{ (4) Prospects of success } \\
\hline Predictors & (a) & (b) & (a) & (b) \\
\hline Constant & 6.142 & 6.373 & -0.421 & 0.218 \\
\hline In-house production & $-0.188^{* * *}$ & $-0.177^{* * *}$ & -0.002 & -0.002 \\
\hline \multicolumn{5}{|l|}{ Outsourcing t-1; t-3 } \\
\hline $\begin{array}{l}\text { :Costs } \\
: \text { Strategy }\end{array}$ & $\begin{array}{l}-0.345 \\
-4.713^{*}\end{array}$ & $\begin{array}{r}3.463 \\
-4.342\end{array}$ & $\begin{array}{l}0.365^{*} \\
0.419 \ddagger\end{array}$ & $\begin{array}{l}0.223 \\
0.915^{\star \star \star}\end{array}$ \\
\hline Innovation $\mathrm{t}-1 ; \mathrm{t}-3$ & -0.564 & -0.686 & $0.263 \ddagger$ & 0.013 \\
\hline Diversification $\mathrm{t}-1 ; \mathrm{t}-3$ & -0.123 & 0.713 & -0.049 & -0.366 \\
\hline Amount of employees & $0.323^{* * *}$ & $0.288^{* * *}$ & 0.000 & -0.000 \\
\hline \multicolumn{5}{|l|}{ General economy } \\
\hline $\begin{array}{l}:- \\
:+ \\
:+++\end{array}$ & $\begin{array}{l}1.023 \\
1.328 \\
1.228\end{array}$ & $\begin{array}{l}4.975 \\
1.894 \\
0.509\end{array}$ & $\begin{array}{l}0.914 f \\
1.540^{\star * *} \\
2.060^{\star * *}\end{array}$ & $\begin{array}{l}0.753 \\
1.150^{*} \\
1.580^{* * *}\end{array}$ \\
\hline$n$ & 745 & 616 & 745 & 616 \\
\hline $\mathrm{R}^{2}$ & $0.911^{* * *}$ & $0.793^{\star * *}$ & $0.061^{* * *}$ & $0.054^{* * *}$ \\
\hline
\end{tabular}

${ }^{* * *} p \leq 0.000 ;{ }^{* *} p \leq 0.001 ;{ }^{*} p \leq 0.05 ; \ddagger p \leq 0.10$ 
Table 6 b: Longitudinal surveys

\begin{tabular}{|c|c|c|c|c|}
\hline \multirow{2}{*}{$\begin{array}{l}\text { Target variables } \\
\text { Predictors }\end{array}$} & \multicolumn{2}{|c|}{ (5) Turnover } & \multicolumn{2}{|c|}{ (6) Prospects of success } \\
\hline & (a) & (b) & (a) & (b) \\
\hline Constant & $8.671 \ddagger$ & 4.992 & -0.562 & -0.466 \\
\hline \multicolumn{4}{|l|}{ Outsourcing } & $-0.010^{*}$ \\
\hline :Costs & 0.516 & $5.790 \ddagger$ & $0.577^{* *}$ & 0.415 \\
\hline :Strategy & $-4.533 \ddagger$ & $-17.791^{\star *}$ & $0.653^{*}$ & $1.160 \ddagger$ \\
\hline :Costs/Strategy & $-4.415 \ddagger$ & -5.289 & $0.499 \ddagger$ & 0.240 \\
\hline :Change & -2.432 & -1.954 & 0.130 & 0.327 \\
\hline \multicolumn{5}{|l|}{ Innovation } \\
\hline :Innovation & -2.644 & -2.027 & 0.127 & 0.219 \\
\hline :Change & $-4.835^{*}$ & -0.051 & -0.033 & -0.001 \\
\hline \multicolumn{5}{|l|}{ Diversification } \\
\hline :Diversification & 0.858 & 0.926 & -0.260 & -0.184 \\
\hline :Change & -1.872 & -1.720 & 0.292 & 0.061 \\
\hline \multicolumn{5}{|l|}{ General economic } \\
\hline :- & 2.088 & 1.646 & $0.948^{*}$ & $1.561^{*}$ \\
\hline :+ & 2.422 & 4.394 & $1.610^{* * *}$ & $2.015^{* * *}$ \\
\hline$:++$ & 2.080 & 4.682 & $2.200^{* \star \star}$ & $2.424^{* \star *}$ \\
\hline$n$ & 712 & 431 & 713 & 427 \\
\hline$R^{2}$ & $0.913^{\star \star \star *}$ & $0.878^{\star \star \star *}$ & $0.074^{* * *}$ & $0.075^{\star \star \star *}$ \\
\hline
\end{tabular}

${ }^{* * *} p \leq 0.000 ;{ }^{* *} p \leq 0.001 ;{ }^{*} p \leq 0.05 ; \ddagger p 0.10$

This model type of panel regression uses an additional dummy variable for each company surveyed to control the company-specific variation (within estimator). Modeling (b) additionally controls for time effects. The dummy variables of the years surveyed the variation that applies to all observed companies in the year of reference.

Models 3 and 4 show the results of regression with time-delayed predicators on the effectiveness, mass turnover, and success for the year 1998. The model variant (a) uses a "time lag" of one year for the outsourcing and / or the strategy decision. This means only those companies questioned in the eight and seventh wave are accounted for. All other predicators refer to the survey of the target variables, that is, the eighth wave. The model variants (b) stretch back two years past. That means that outsourcing and strategy decisions from 1995 are accounted for.

Models 5 and 6 in contrast account for whether a shift in the decision for outsourcing and/or competitive strategies of innovation and diversification took place during the period. As far as the decision for outsourcing is concerned, a distinction is made between cases where the company constantly decided against outsourcing (basis category) or consistently maintained an outsourcing strategy due to cost (category: Outsourcing: costs) and or if they continue with outsourcing-strategy (category: outsourcing: strategy). In terms of the "changers," a further distinction is made between companies that change the reasons for outsourcing $r$ (category outsourcing costs /strategy) and/or during the period begin to refrain from outsourcing measures (category: outsourcing changers). In terms of the competitive options, it is decided whether the companies maintain a strategy or not. Model variant (a) accounts for the constancy and/or change in the time window 1997-1998, that is, for waves seven and eight of 
the NIFA panel. In the model variant (b), in contrast, the change or constancy is accounted for over the entire period of the four waves the survey time points 19951998.

The results of the panel models ( 1 and 2 in table 6a), based on 5064 observations at 2674 companies over a four year time frame do not differ fundamentally from the previous cross-sectional analyses. In terms of the degree of effectiveness "turnover," it is evident on the basis of the four waves of the NIFA panel that company size has a positive impact and in-house production quotient a negative impact on turnover. All the same, the negative influence of the in-house production quotient proves not significant in terms of "fixed effects" models. In contrast, I can report on the broad data basis a positive effect of a diversification strategy on turnover.

The results in terms of the target variable prospects of success are similar. As in the cross-section, in the panel analysis the significantly positive influence of the general economic situation. The subjective degree of success is positively influenced by the decision for outsourcing, in both differentiated categories, as well as the estimation of the overall economic situation. Furthermore the positive finding of the cross-section can be proven in terms of competitive strategy "innovation" in longitudinal section. In terms of both degrees of effectivity, time effects manifest themselves that however do not impact the influence factors at the center of our interest here.

A very similar picture is provided by the regression models with temporally delayed predicators ( 3 and 4 in table 6 a). In terms of these models as well, the most important influential variables on turnover are the number of employees and the inhouse production quotient and/or in terms of the prospects of success the estimation of the overall economic situtation. It should be emphasized that the prospects of success can be influenced on the basis of this analysis over the short term positively as by innovation strategy. Over the long term, that is, with a time gap of four years, among the group of second level variables only strategic outsourcing proves to be a significant predicator for the subjective degree of success.

The expanded regressions with delayed determinants explore the influence of a change in outsourcing and or strategy decision (5 and 6 in table 6b). The results on turnover or success outlook do not show a fundamentally new picture. The major variables of influence are also retained in these model variants. Almost all these variables were not statistically uninfluenced (not significantly) by a change of the decision in the dimensions studied. The turnover of the target year is just as negatively impacted from maintaining the strategic outsourcing (category: outsourcing: strategy) as it is from change in the outsourcing variants. (category: outsourcing: cost/strategy). But a shift to non-outsourcing (category: outsourcing: delay) has an insignificant negative influence on turnover. Considering the data for the overall time period, only the effects for the maintaining one variant of outsourcing remain significant. If in all four years outsourcing was done for cost reasons, outsourcing for cost reasons proves positive for the turnover, whereas strategic outsourcing has a negative impact. The innovation strategy has a negative impact on turnover over the short and the long term. However, only the short-term change from an innovation strategy to a non-innovation strategy can be reported as a significantly negative predicator. The sign of the effect remains over the long term, but it is no longer significant. The diversification strategy 
has, as in the models reported above, a positive impact on the turnover, and a change to the non-diversification strategy proves accordingly negative. All the same these variables of influence are not statistically significant. The subjective degree of effectiveness "prospects of success" is in the short-term view both positively influenced by outsourcing for both cost and strategic reasons. In the long-term analysis, however, only constancy in outsourcing for strategic reasons has a significant impact on success.

\section{Discussion}

Resourcing - outsourcing as a prominent special case - is in this study conceived of as an organizational measure that changes the dependence of organizations. From the RDA point of view, organizations account for situational resource dependency in deciding for or against outsourcing, to free themselves from resource control of other actors. On the theoretical level, this RDA perspective offers advantages vis-à-vis alternative explanations from TCA or RBV that dominate the debate. TCA, with the focus on the situational favorableness of specific organizational arrangements, neglects the strategic character of organizational decisions. RBV, with accounts for strategy, tends to fail to account for power in external relations due to the emphasis on internal resources. All the same, RDA also requires expansion: corporate or competitive strategies should be included explicitly with organizational changes in mind.

We have concretized the theoretical argument by using a longitudinal data set on the reorganization of the German engine building in the 1990s. The operationalizaiton of the determinants behind resourcing decisions comprise on the one hand the external and internal resource dependence of the company and on the other hand their competition strategy. The operationalizations possible on the basis of the secondary analysis contain both general determinants of resource dependency and competition strategies as well as specific aspects of industrial relations in the national setting of the study.

Both cross-sectional and longitudinal analyses confirm the general RDA hypothesis that organizations try to free themselves from the influence of other actors in resource decisions. Especially in terms of cross-sectional analyses, it can be established that a large number of the supposed positive and negative influence relations cannot be confirmed or refuted. That many influence variables remain without empirical confirmation is probably due to the nature of a secondary analytic research strategy. The predicators used are only partially adapted directly towards the theoretical framework. No conclusive findings can be made on the basis of the few findings that ran contrary to the hypotheses, that on the one hand can report of an indicator of the customer and provider influence as well as on the other hand in terms of a specific variable on the improving on the level of the company, to the extent these falsifications can be attributed to the theoretical framework or, due to the secondary analytic access, a mistaken operationalizaiton.

The general confirmation of the theoretical framework and the derived hypothesis encourage us to work in the further in this direction. Primary studies on organizational measures would be important that make possible operationalizations closer to the core concept of the RDA - the striving toward independence from external control. To the extent that the effecivity of these measures are also to be shown, longitu- 
dinal studies, like the findings of the panel analysis in this work underscore - are absolutely necessary.

\section{References}

Aldrich, H. E./Pfeffer, J. (1976): Environments of organizations. In: Annual Review of Sociology, 2: 79105.

Ang, S./Cummings, L. L. (1997): Strategic response to institutional influences on information systems outsourcing. In: Organization Science, 8(3): 235-256.

Ansoff, I. (1965): Checklist for Competitive and Competence Profiles. New York: Mc Graw Hill.

Aubert, B. A./Rivard, S./Patry, M. (1996): A transaction cost approach to outsourcing behavior: Some empirical evidence. In: Information \& Management, 30(2): 51-65.

Coleman, J. S. (1990): Foundations of Social Theory. Cambridge/Mass.: Havard University Press.

Cox, D./Wermuth, N. (1993): Linear dependencies represented by chain graphs. In: Statistical Science, 8: 204-218.

Delmestri, G. (2002): Institutionen, Technik und Ökonomie - Eine organisationstheoretische Untersuchung des deutschen und italienischen Maschinenbaus. München, Mering: Hampp.

Drucker, P. F. (1988): The coming of the new organization. In: Harvard Business Review (JanuaryFebruary).

Drumm, H. J. (1996): Das Paradigma der Neuen Dezentralisation. In: Die Betriebswirtschaft, 56(1): 7-20.

Duschek, S. (2004): Inter-firm resources and sustained competitive advantage. In: management revue, 15(1): 53-73.

Emerson, R. M. (1962): Power-dependence relations. In: American Sociological Review, 27: 32-41.

Foss K./Foss, N. J. (2004): The Next Step in the Evolution of the RBV:Integration with Transaction Cost Economics. In: management revue, 15(1): 107-121.

Freiling, J. (2001): Resource-based View und ökonomische Theorie - Grundlagen und Positionierung des Ressourcenansatzes. Wiesbaden: Dt. Univ.-Verl.

Gretzinger, S. (2008): Strategische Gestaltung des Outsourcing im deutschen Maschinenbau. München, Mering: Hampp.

Hermesch, M. (2002): Die Gestaltung von Interorganisationsbeziehungen. Köln:Eul.

Hirsch-Kreinsen, H./Seitz, B. (2000): Der Maschinenbau als Entwickler von Produktions- und Fertigungstechniken. In: Widmaier, U. (Hg.): Der Deutsche Maschinenbau in den neunziger Jahren: Kontinuität und Wandel einer Branche. Frankfurt am Main, New York: Campus: 43-65.

Klaas, B. S./J., M./Gainey, T. W. (1999): HR outsourcing and its impact: The role of transaction costs. In: Personnel Psychology, 52(1): 113-136 .

Kotthoff, H. (1994): Betriebsräte und Bürgerstatus. München/Mering: Hampp.

Leyendecker, H. W. (2000): Der Wandel der Betriebsorganisation im deutschen Maschinenbau in den 90er Jahren. In: Widmaier, U. (Hg.): Der deutsche Maschinenbau in den neunziger Jahren - Kontinuitäten und Wandel einer Branche. Frankfurt am Main, New York: Campus: 307-325.

Langlois, R. N. (1988): Economic change and the boundaries of the firm. In: Journal of Institutional and Theoretical Economics, 144(4): 635-657.

Lauritzen, S. L./Wermuth, N. (1989): Graphical models for association between variables, some of which are qualitative and some quantitative. In: Annals of Statistics, 15: 31-57.

March, J. G./Simon, H. A. (1994): Organizations. 2nd edition. Cambridge,Mass.: Blackwell.

Matiaske, W. (2009): Social Capital in Organisations, 2nd edition. Cambridge:Cambridge Scholar Publ. (in print).

Matiaske, W./Kabst, R. (2002): Outsourcing und Professionalisierung in der Personalarbeit. Eine transaktionskostentheoretisch orientierte Studie. In: Martin, A./Nienhüser, W. (Hg.): Neue Formen der Beschäftigung - Neue Personalpolitik? München, Mering: Hampp: 247-271.

Matiaske, W./Mellewigt, T. (2002): Motive, Erfolge und Risiken des Outsourcings - Befunde und Defizite der empirischen Outsourcing-Forschung. In: Zeitschrift für Betriebswirtschaft, 72(6): 641-659.

Maurice, M./Sorge, A. (1990): Industrielle Entwicklung und Innovationsfähigkeit der Werkzeugmaschinenhersteller in Frankreich und der Bundesrepublik Deutschland - Gesellschaftliche Analyse der 
Beziehungen zwischen Qualifikation und Wirtschaftsstruktur. Arbeitspapier, Nr. FS I 90 11, Wissenschaftszentrum Berlin für Sozialforschung.

Mellewigt, T. (2003): Management von Strategischen Kooperationen. Wiesbaden: Dt. Univ.-Verl.

Müller-Jentsch, W./Seitz, B. (1998): Betriebsräte gewinnen Konturen. Ergebnisse einer BetriebsräteBefragung im Maschinenbau. In: Industrielle Beziehungen, 5(4): 361-387.

Nienhüser, W. (2004): Die Resource-Dependence-Theorie: Wie (gut) erklärt sie Unternehmensverhalten? In: Festing, M./Martin, A./Mayrhofer/W./Nienhüser, W. (Hg.: Personaltheorie als Beitrag zur Theorie der Unternehmung. München, Mering: Hampp: 87-119.

Nienhüser, W. (2008): Resource Dependence Theory: How well does it explain behavior in organizations. In: management revue, 19(1+2): 9-32.

Penrose, E. T. (1959): The Theory of the Growth of the Firm. Oxford: Oxford University Press.

Pfeffer, J./Salancik, G. R. (1978): The External Control of Organizations - A Resource Dependence Perspective. New York: Harper \& Row.

Picot, A. (1991): Ein neuer Ansatz zur Gestaltung der Leistungstiefe. In: Zeitschrift für betriebswirtschaftliche Forschung, 43, 336-357.

Poppo, L./Zenger, T. (1998): Testing alternative theories of the firrm:Transaction cost, knowledgebase and measurement explanations to make-or-buy decisions in information services. In: Strategic Management Journal, 19: 853-877.

Porter, M. E. (1998): Competitive advantage: Creating and sustaining superior performance. 2nd edition, New York: Free Press.

Prahalad, C. K./Hamel, G. (1990): The core competence of the corporation. In: Harvard Business Review, (3): 79-91

Stock, J. H./Watson, M. W. (2003): Introduction to Econometrics. Boston et al.: Pearson.

Szyperski, N. (1993): Outsourcing als strategische Entscheidung. In: Online (2): 32-34.

Trossmann, E. (2002): Beschaffung und Logistik. In: Bea, F. X./Dichtl, E./Schweitzer, M.,( eds.), Allgemeine Betriebswirtschaftslehre: Vol 3: Leistungsprozess. 8. edition, Stuttgart: Lucius \& Lucius: $77-$ 142.

Turvani, M. (2001): Reading Edith Penrose's The Theory of the Growth of the Firm forty years on (1959-1999). In: Garrouste, P./Ioannides, S. (eds.): Evolution and path dependence in economic ideas: past and present. Cheltenham: Elgar: 148-178.

Walker, G./Weber, D. (1984): A transaction cost approach to make-or-buy decisions. In: Administrative Science Quarterly, 29: 373-391.

Wernerfelt, B. (1984): A resource-based view of the firm. In: Strategic Management Journal, 5(2): 171180.

Wernerfelt, B. (1995): The resource-based view of the firm: Ten years after. In: Strategic Management Journal, 16: 171-174.

Widmaier, U. (2000a): Das NIFA-Panel und der deutsche Maschinen- und Anlagenbau. In: Der deutsche Maschinenbau in den neunziger Jahren - Kontinuitäten und Wandel einer Branche. Frankfurt am Main, New York: Campus: 23-41.

Widmaier, U. (2000b): Kontinuitäten und Wandel der Betriebsorganisation im deutschen Maschinenbau. In: Widmaier, U. (Hg.): Betriebliche Rationalisierung und ökonomische Rationalität - Optionen und Determinanten von Differenzierungsprozessen im deutschen Maschinenbau. Frankfurt am Main, New York: Campus: 279-305.

Williamson, O. E. (1985): The Economic Institutions of Capitalism: Firms, Markets, Relational Contracting. New York: Free Press.

Williamson, O. E. (1986): Vertical integration and related variations on a transaction-cost economics theme. In: New Developments in the Analysis of Market Structure. Basingstoke: Macmillan: 149176.

Wooldridge, J. M. (2006): Introductory Econometrics: A Modern Approach. $3^{\text {rd }}$ edition, Mason: Thomson.

Zajac, E. J./Olson, C. P. (1993): From transaction cost to transaction value analysis: Implications for the study of interorganizational strategies. In: Journal of Management Studies, 30: 131-145. 


\section{Appendix}

Table 4: Arithmetic mean, variance and correlations of the variables

\begin{tabular}{|c|c|c|c|c|c|c|c|c|c|c|c|c|c|c|}
\hline & Terms of Variables & $n$ & mean & s & 1 & 2 & 3 & 4 & 5 & 6 & 7 & 8 & 9 & 10 \\
\hline 1 & Turnover & 1630 & 33.95 & 76.62 & & & & & & & & & & \\
\hline 2 & Prospects of success* & 1627 & 2.00 & - & -0.005 & & & & & & & & & \\
\hline 3 & Outsourcing** & 1669 & 0.64 & - & 0.131 & 0.096 & & & & & & & & \\
\hline 4 & Insoursing** & 1662 & 0.20 & - & 0.102 & 0.052 & 0.039 & & & & & & & \\
\hline 5 & In-house production & 1621 & 62.75 & 24.53 & -0.175 & 0.020 & -0.107 & 0.000 & & & & & & \\
\hline 6 & Innovation strategy ${ }^{* *}$ & 1624 & 0.57 & - & 0.025 & 0.090 & -0.021 & -0.006 & -0.067 & & & & & \\
\hline 7 & $\begin{array}{l}\text { Diversification } \\
\text { strategy* }^{*}\end{array}$ & 1610 & 0.17 & - & -0.021 & -0.021 & 0.031 & 0.027 & 0.029 & 0.002 & & & & \\
\hline 8 & $\begin{array}{l}\text { General economic } \\
\text { situation* }\end{array}$ & 1688 & 3.00 & - & 0.026 & 0.185 & 0.025 & -0.026 & 0.031 & 0.033 & 0.022 & & & \\
\hline 9 & Employment contract** & 1679 & 0.56 & - & 0.230 & -0.023 & 0.091 & -0.012 & -0.054 & -0.003 & -0.036 & -0.021 & & \\
\hline 10 & $\begin{array}{l}\text { Influence of the } \\
\text { suppliers**}\end{array}$ & 1602 & 0.27 & - & 0.031 & 0.102 & 0.084 & 0.028 & -0.076 & 0.037 & 0.012 & 0.023 & -0.038 & \\
\hline 11 & $\begin{array}{l}\text { Cooperation in } \\
\text { purchase }^{\star *}\end{array}$ & 1671 & 0.12 & - & 0.103 & 0.097 & 0.075 & 0.063 & -0.050 & -0.027 & 0.009 & -0.010 & 0.029 & 0.449 \\
\hline 12 & $\begin{array}{l}\text { Longterm relationship } \\
\text { to victualers }{ }^{\star \star}\end{array}$ & 1604 & 0.31 & - & 0.187 & 0.074 & 0.078 & 0.113 & -0.212 & 0.009 & 0.020 & 0.017 & 0.051 & 0.101 \\
\hline 13 & Custoremer influence ${ }^{\star *}$ & 1642 & 0.45 & - & 0.026 & 0.061 & 0.038 & 0.014 & 0.000 & -0.007 & 0.016 & 0.019 & 0.032 & 0.065 \\
\hline 14 & $\begin{array}{l}\text { Turnover with regular } \\
\text { customers }\end{array}$ & 1628 & 71.60 & 21.97 & -0.046 & -0.029 & -0.022 & 0.001 & 0.140 & 0.003 & -0.026 & 0.052 & 0.011 & -0.025 \\
\hline 15 & $\begin{array}{l}\text { Cooperation in } \\
\text { Distribution** }\end{array}$ & 1671 & 0.20 & - & 0.051 & 0.055 & 0.063 & 0.006 & -0.096 & 0.067 & 0.011 & -0.009 & 0.010 & 0.646 \\
\hline 16 & $\begin{array}{l}\text { Longterm customer } \\
\text { relation** }\end{array}$ & 1688 & 0.27 & - & 0.002 & 0.056 & -0.025 & 0.048 & 0.006 & -0.004 & 0.016 & 0.050 & 0.023 & 0.131 \\
\hline 17 & $\begin{array}{l}\text { Linkages with parent } \\
\text { companies }^{* \star}\end{array}$ & 1684 & 0.36 & - & 0.243 & 0.074 & 0.107 & 0.068 & -0.186 & -0.014 & -0.018 & 0.005 & 0.219 & 0.110 \\
\hline 18 & Work council ${ }^{* *}$ & 1684 & 0.63 & - & 0.239 & 0.016 & 0.160 & 0.023 & -0.102 & 0.049 & -0.061 & -0.011 & 0.386 & 0.041 \\
\hline 19 & $\begin{array}{l}\text { Volume of order in } \\
\text { weeks }\end{array}$ & 1683 & 14.53 & 11.93 & 0.252 & 0.009 & 0.112 & -0.033 & -0.120 & 0.059 & 0.015 & -0.008 & 0.056 & 0.005 \\
\hline 20 & $\begin{array}{l}\text { Made to order } \\
\text { production in \% }\end{array}$ & 1660 & 36.51 & 37.09 & -0.095 & -0.021 & 0.061 & -0.109 & 0.038 & -0.129 & 0.006 & -0.005 & -0.016 & -0.054 \\
\hline 21 & $\begin{array}{l}\text { Customer's } \\
\text { specification in \% }\end{array}$ & 1683 & 59.65 & 37.10 & -0.118 & 0.012 & -0.040 & -0.068 & 0.180 & -0.081 & 0.019 & -0.001 & -0.078 & -0.045 \\
\hline 22 & $\begin{array}{l}\text { Manufacturing without } \\
\text { order in } \%\end{array}$ & 1685 & 14.74 & 18.43 & 0.086 & 0.036 & 0.022 & 0.074 & -0.057 & 0.069 & 0.024 & 0.013 & -0.011 & 0.070 \\
\hline 23 & Amount of employees & 1697 & 143.40 & 349.51 & 0.899 & -0.038 & 0.097 & 0.087 & -0.083 & 0.008 & -0.004 & 0.011 & 0.207 & -0.002 \\
\hline 24 & Skilled employees in \% & 1625 & 0.49 & 0.21 & -0.184 & -0.012 & -0.023 & -0.099 & 0.258 & -0.064 & 0.037 & -0.012 & -0.055 & -0.017 \\
\hline
\end{tabular}

Ordinal (quartile separation), median instead of arithmetic mean, Spearmans $p$ instead Pearsons $r$.

** binery bzw. dichotomised, arithmetic mean, share existent. 
Table 4: Arithmetic mean, variance and correlations of the variables (continued)

\begin{tabular}{|c|c|c|c|c|c|c|c|c|c|c|c|c|c|c|}
\hline & Terms of Variables & 11 & 12 & 13 & 14 & 15 & 16 & 17 & 18 & 19 & 20 & 21 & 22 & 23 \\
\hline 1 & Turnover & & & & & & & & & & & & & \\
\hline 2 & Prospects of success* & & & & & & & & & & & & & \\
\hline 3 & Outsourcing ${ }^{* *}$ & & & & & & & & & & & & & \\
\hline 4 & Insoursing ${ }^{\star *}$ & & & & & & & & & & & & & \\
\hline 5 & In-house production & & & & & & & & & & & & & \\
\hline 6 & Innovation strategy** & & & & & & & & & & & & & \\
\hline 7 & $\begin{array}{l}\text { Diversification } \\
\text { strategy }^{* *}\end{array}$ & & & & & & & & & & & & & \\
\hline 8 & $\begin{array}{l}\text { General economic } \\
\text { situation* }\end{array}$ & & & & & & & & & & & & & \\
\hline 9 & Employment contract ${ }^{\star *}$ & & & & & & & & & & & & & \\
\hline 10 & $\begin{array}{l}\text { Influence of the } \\
\text { suppliers* }^{* *}\end{array}$ & & & & & & & & & & & & & \\
\hline 11 & $\begin{array}{l}\text { Cooperation in } \\
\text { purchase }^{* *}\end{array}$ & & & & & & & & & & & & & \\
\hline 12 & $\begin{array}{l}\text { Longterm relationship } \\
\text { to victualers** }\end{array}$ & 0.078 & & & & & & & & & & & & \\
\hline 13 & Custoremer influence $^{\star *}$ & 0.033 & 0.086 & & & & & & & & & & & \\
\hline 14 & $\begin{array}{l}\text { Turnover with regular } \\
\text { customers }\end{array}$ & -0.019 & -0.956 & 0.095 & & & & & & & & & & \\
\hline 15 & $\begin{array}{l}\text { Cooperation in } \\
\text { Distribution** }\end{array}$ & 0.334 & 0.052 & 0.002 & -0.027 & & & & & & & & & \\
\hline 16 & $\begin{array}{l}\text { Longterm customer } \\
\text { relation** }\end{array}$ & 0.070 & 0.274 & 0.144 & 0.160 & 0.085 & & & & & & & & \\
\hline 17 & $\begin{array}{l}\text { Linkages with parent } \\
\text { companies }^{\star *}\end{array}$ & 0.168 & 0.176 & 0.019 & -0.037 & 0.126 & 0.042 & & & & & & & \\
\hline 18 & Work council ${ }^{* *}$ & 0.059 & 0.077 & -0.001 & -0.063 & 0.042 & 0.028 & 0.247 & & & & & & \\
\hline 19 & $\begin{array}{l}\text { Volume of order in } \\
\text { weeks }\end{array}$ & 0.034 & 0.007 & 0.009 & -0.036 & 0.028 & 0.002 & 0.0073 & 0.130 & & & & & \\
\hline 20 & Made to order in $\%$ & -0.069 & -0.210 & -0.002 & -0.082 & -0.034 & -0.192 & -0.087 & -0.061 & 0.126 & & & & \\
\hline 21 & $\begin{array}{l}\text { Customer's } \\
\text { specification in \% }\end{array}$ & -0.053 & -0.166 & 0.097 & 0.061 & -0.078 & -0.007 & -0.130 & -0.071 & 0.150 & 0.415 & & & \\
\hline 22 & $\begin{array}{l}\text { Manufacturing without } \\
\text { order in } \%\end{array}$ & 0.015 & 0.104 & -0.008 & 0.010 & 0.068 & 0.043 & 0.025 & -0.012 & -0.175 & -0.217 & -0.301 & & \\
\hline 23 & Amount of employees & 0.044 & 0.152 & 0.003 & -0.024 & 0.017 & 0.021 & 0.196 & 0.220 & 0.179 & -0.089 & 0.053 & -0.110 & \\
\hline 24 & Skilled employees in \% & -0.001 & -0.162 & 0.039 & 0.052 & -0.033 & 0.005 & -0.141 & -0.066 & 0.002 & 0.185 & -0.138 & 0.272 & -0.147 \\
\hline
\end{tabular}

* Ordinal (quartile separation), median instead of arithmetic mean, Spearmans $p$ instead Pearsons $r$.

** binery bzw. dichotomised, arithmetic mean, share existent 
Table 7a: Likert-Skalierung victualers influence

(Reference: NIFA-Panel 1997, own calculations)

\begin{tabular}{l|c|c|c|c}
\hline \multicolumn{1}{l}{ Victualers exerting influence (ratings with three ranks) } \\
\hline & $\begin{array}{c}\text { Discriminatory } \\
\text { power }\end{array}$ & $\begin{array}{c}\text { Arithmetic mean of } \\
\text { the scale }\end{array}$ & $\begin{array}{c}\text { Variance of the } \\
\text { scale }\end{array}$ & $a$ \\
\hline Personal planning & 0.50 & 3.69 & 9.61 & 0.79 \\
Capital budgeting & 0.55 & 3.53 & 8.97 & 0.78 \\
Operational procedures & 0.55 & 3.58 & 9.22 & 0.78 \\
Organization & 0.54 & 3.59 & 9.23 & 0.78 \\
Manufacturing program & 0.52 & 3.49 & 9.10 & 0.78 \\
Sales planning & 0.48 & 3.35 & 8.87 & 0.79 \\
Product engineering & 0.50 & 3.05 & 8.68 & 0.79 \\
Quality & 0.52 & 3.28 & 8.67 & 0.78 \\
\hline
\end{tabular}

$N=534 ;$ Conbachs $\alpha=0.804$

Table 7b: Likert-Skalierung customers influence

(Reference: NIFA-Panel 1997, own calculations)

Customers exerting influence (ratings with three ranks)

\begin{tabular}{l|c|c|c|c}
\hline & $\begin{array}{c}\text { Discriminatory } \\
\text { power }\end{array}$ & $\begin{array}{c}\text { Arithmetic mean of } \\
\text { the scale }\end{array}$ & $\begin{array}{c}\text { Variance of the } \\
\text { scale }\end{array}$ & $a$ \\
\hline Personal planning & 0.54 & 5.10 & 11.67 & 0.82 \\
Capital budgeting & 0.65 & 4.90 & 10.85 & 0.80 \\
Operational procedures & 0.62 & 4.93 & 11.06 & 0.81 \\
Organization & 0.62 & 5.12 & 11.55 & 0.81 \\
Manufacturing program & 0.57 & 4.91 & 11.37 & 0.82 \\
Sales planning & 0.59 & 4.72 & 10.59 & 0.81 \\
Product engineering & 0.42 & 4.32 & 11.54 & 0.84 \\
Quality & 0.55 & 4.29 & 11.07 & 0.82 \\
\hline
\end{tabular}

$N=1642 ;$ Conbachs $a=0.845$ 